\title{
PERSEPSI REMAJA TERHADAP PEKERJAAN DI SEKTOR PERTANIAN PADI SAWAH DI DESA CILEUNGSI KECAMATAN CIAWI KABUPATEN BOGOR
}

\section{Adolescent Perception of Lowland Rice Farming at Cileungsi Village, Ciawi Subdistrict, Bogor Regency}

\author{
Yoshinta Meilina $^{1)}$ dan Ratri Virianita ${ }^{1)}$ \\ ${ }^{1)}$ Departemen Sains Komunikasi dan Pengembangan Masyarakat, Fakultas Ekologi Manusia, \\ Institut Pertanian Bogor, Darmaga Bogor 16680, Indonesia \\ Email: yoshintameilina@yahoo.com; ratru_v@apps.ipb.ac.id
}

\begin{abstract}
Cileungsi Village, Ciawi Subdistrict, Bogor Regency is one of the potential areas of lowland rice farming. Adolescent of Cileungsi Village as the age of the workforce will be observed for their perceptions in farming. This research aims to identify the characteristics of adolescents and their environment, to analyze adolescent perceptions of lowland rice farming and factors which related with the adolescent of Cileungsi Village perception. The method of this research is survey method. The result obtained by the internal factors (educational level and gender) related with adolescent of the village's perception (role and work comfort) about lowland rice farming.
\end{abstract}

Keywords: lowland rice, perception, adolescent

\begin{abstract}
ABSTRAK
Desa Cileungsi, Kecamatan Ciawi, Kabupaten Bogor, merupakan salah satu daerah yang memiliki potensi alam yang mendukung untuk pertanian padi sawah. Remaja Desa Cileungsi sebagai salah satu orang dengan usia yang termasuk dalam angkatan kerja, akan diteliti persepsinya terhadap pekerjaan di sektor pertanian padi sawah. Penelitian ini bertujuan untuk mengidentifikasi karakteristik remaja dan karakteristik lingkungan remaja di Desa Cileungsi, menganalisis persepsi remaja Desa Cileungsi terhadap pekerjaan di sektor pertanian padi sawah, dan mengetahui faktor-faktor apa saja yang berhubungan dengan persepsi remaja Desa Cileungsi terhadap pekerjaan di sektor pertanian padi sawah. Penelitian ini dilakukan dengan menggunakan metode penelitian survei. Adapun hasil penelitian yang diperoleh yaitu faktor internal (tingkat pendidikan dan jenis kelamin) berhubungan dengan persepsi remaja Desa Cileungsi (dalam hal peranan dan kenyamanan kerja) terhadap pekerjaan di sektor pertanian padi sawah.
\end{abstract}

Kata kunci: padi sawah, persepsi, remaja

\section{PENDAHULUAN}

Sektor pertanian merupakan sektor yang sangat berperan penting dalam pembangunan ekonomi Indonesia. Dari ke empat sektor produksi yaitu pertanian, perindustrian, pertambangan dan perdagangan (jasa), yang jumlahnya 100 persen pada setiap tahun, maka peran sektor pertanian dalam PDB pada tahun 1939 adalah 61 persen, sedangkan peran atau kontribusi ke tiga sektor lainnya hanya 39 persen (Tarigan 2006). Pada fase awal pembangunan ekonominya, penduduk Indonesia juga banyak menggantungkan pendapatan hidupnya pada sektor pertanian dan sebagian besar tenaga kerja Indonesia bekerja di sektor pertanian karena sektor pertanian berkontribusi dalam penyerapan tenaga kerja dan tidak diperlukan keterampilan yang tinggi untuk mengerjakannya.

Meskipun pembangunan pertanian ditetapkan menjadi prioritas dengan target peningkatan produktivitas pangan untuk mencapai swasembada beras, namun kenyataan menunjukkan gerakan industrialisasi mengalami perkembangan lebih pesat. Mereka yang terjun ke dunia kerja, lebih senang mengadu nasib untuk bekerja di kota, dengan harapan akan mendapat kehidupan yang lebih baik.

Telah terjadi fenomena penurunan jumlah tenaga kerja di sektor pertanian dari tahun ke tahun. Berdasarkan hasil Sensus Pertanian 2013, jumlah rumah tangga usaha pertanian di Indonesia mengalami penurunan sebanyak 5,04 juta rumah tangga dari 31,17 juta rumah tangga pada tahun 
2003 (Sensus Pertanian 2003) menjadi 26,13 juta rumah tangga pada tahun 2013, yang berarti ratarata penurunan per tahun sebesar 1,75 persen (BPS 2013). Penurunan jumlah tenaga kerja di sektor pertanian termasuk juga dari generasi muda. Penurunan jumlah petani usia muda tersebut disebabkan oleh keinginan pemuda desa yang sudah memudar untuk bekerja di sektor pertanian, dan lebih cenderung memilih pekerjaan di sektor luar pertanian, baik di daerah desa tempat tinggalnya maupun di daerah perkotaan.

Menurut Undang-undang No. 25 tahun 1997, tenaga kerja didefinisikan sebagai penduduk berusia 15 tahun atau lebih. Oleh karena itu, usia remaja juga termasuk dalam usia angkatan kerja. Di beberapa daerah, terutama di pedesaan, anak usia remaja bahkan sudah dijadikan pekerja untuk menambah penghasilan orang tuanya, termasuk membantu dengan menjadi tenaga kerja di sektor pertanian. Sebelum mereka menentukan untuk memilih jenis pekerjaan yang akan mereka tekuni, mereka terlebih dahulu mempunyai suatu pandangan mengenai jenis pekerjaan tersebut. Dalam hal ini, remaja desa mempunyai persepsi tersendiri mengenai pekerjaan di sektor pertanian. Persepsi merupakan pemahaman individu terhadap informasi lingkungan yang diperoleh melalui proses kognitif (Toha 1983 yang dikutip oleh Maria 2007). Proses pembentukan persepsi remaja dapat terbentuk karena dipengaruhi faktor internal sebagai faktor yang berasal dari dalam diri sendiri, dan faktor eksternal yang berasal dari luar diri remaja tersebut. Penilaian tentang pekerjaan di sektor pertanian yang dilakukan oleh remaja berdasarkan pengamatan yang dilakukannya sendiri yang terkait dengan tingkat pendidikan, pengalaman, dan jenis kelamin. Penilaian tersebut juga berdasarkan proses sosialisasi yang dilakukan orang-orang di sekelilingnya, yaitu teman-teman dan keluarganya, juga berdasarkan status kepemilikan lahan sawah.

Berdasarkan informasi dari BP3K (Badan Penyuluhan Pertanian, Perikanan, Kehutanan), Desa Cileungsi, Kecamatan Ciawi, Kabupaten Bogor, merupakan salah satu daerah yang memiliki gabungan kelompok tani (gapoktan) yang tergolong maju. Berdasarkan data monografi tahun 2010, Desa Cileungsi juga memiliki lahan persawahan yang cukup luas, yakni 160.309 hektar yang didominasi oleh tanaman pangan, sehingga tak heran jika komoditas yang paling besarnya ialah padi sawah. Sebagian besar penduduk Desa Cileungsi bermata pencaharian sebagai petani dan buruh tani. Berdasarkan informasi yang didapat dari hasil penjajakan peneliti dengan pegawai kantor desa, hampir semua jumlah petani dan buruh tani yang terdapat di Desa Cileungsi ialah petanipetani yang tergolong tua. Peneliti ingin melihat apakah remaja di Desa Cileungsi tersebut akan mengikuti jejak para orang tua mereka yang bekerja sebagai petani, terkait dengan faktor internal dan eksternal yang mempengaruhinya. Oleh karena itu, Desa Cileungsi menarik untuk diteliti persepsi remajanya terhadap pekerjaan di sektor pertanian, dalam hal ini sektor pertanian lebih difokuskan pada tanaman padi sawah.

Oleh karena itu, masalah penelitian dirumuskan sebagai berikut:

1. Bagaimana karakteristik remaja dan karakteristik lingkungan remaja di Desa Cileungsi, Kecamatan Ciawi, Kabupaten Bogor?

2. Bagaimana persepsi remaja Desa Cileungsi terhadap pekerjaan di sektor pertanian padi sawah?

3. Faktor-faktor apa saja yang berhubungan dengan persepsi remaja Desa Cileungsi terhadap pekerjaan di sektor pertanian padi sawah?

Merujuk pada permasalahan penelitian, maka tujuan penelitian dirumuskan sebagai berikut:

1. Mengidentifikasi karakteristik remaja dan karakteristik lingkungan remaja di Desa Cileungsi, Kecamatan Ciawi, Kabupaten Bogor.

2. Menganalisis persepsi remaja Desa Cileungsi terhadap pekerjaan di sektor pertanian padi sawah.

3. Mengetahui faktor-faktor yang berhubungan dengan persepsi remaja Desa Cileungsi terhadap pekerjaan di sektor pertanian padi sawah.

\section{PENDEKATAN TEORITIS}

\section{Pekerjaan Di Sektor Pertanian Padi Sawah}

Istilah pekerjaan digunakan untuk suatu tugas atau kerja yang menghasilkan uang bagi seseorang. Pada pembicaraan sehari-hari istilah 
ini sering dianggap sinonim dengan profesi ${ }^{1}$. Menurut Liu dan Madiono (2013), pertanian adalah kegiatan usaha yang meliputi budidaya tanaman pangan, hortikultura, perkebunan, perikanan, kehutanan, dan peternakan. Oleh karena itu dapat disimpulkan pekerjaan di sektor pertanian merupakan suatu kegiatan usaha di bidang tanaman pangan dan hortikultura, perkebunan, perikanan, kehutanan, dan peternakan, agar dapat menghasilkan uang dan dapat memenuhi kebutuhan hidup keluarga atau masyarakat. Sub sektor tanaman pangan dan hortikultura itu sendiri mencakup komoditi bahan makanan seperti padi, jagung, ketela pohon, ketela rambat, umbi-umbian, kacang tanah, kacang kedele, kacang-kacangan lainnya, sayursayuran, dan buah-buahan (Tarigan 2006). Dalam penelitian ini akan lebih difokuskan pada pertanian padi sawah. Adapun jenis pekerjaan yang dilakukan oleh pekerja sektor pertanian padi sawah, yaitu persemaian, pengolahan tanah, penanaman, penyulaman, pemupukan, pengendalian HPT, penyiangan, pengaturan air, dan panen (Jannah et al. 2013). Oleh karena itu dalam penelitian ini pekerjaan di sektor pertanian padi sawah lebih berfokus kepada kegiatankegiatan teknis di lahan pertanian, mulai dari persemaian sampai dengan pemanenan, dan bukan pekerjaan yang berhubungan dengan agribisnis, seperti halnya memasarkan produk pertanian.

\section{Persepsi}

Persepsi memiliki implikasi penting dalam perilaku seseorang, sehingga orang tersebut akan bersikap dan berinteraksi dengan obyek yang dipersepsi tersebut. Persepsi menurut Robbins (2002), adalah suatu proses yang ditempuh oleh setiap individu untuk mengorganisasikan dan menafsirkan kesan indera mereka agar memberi makna kepada lingkungan mereka. Toha (1983) yang dikutip oleh Maria (2007) mengatakan bahwa persepsi merupakan pemahaman individu terhadap informasi lingkungan yang diperoleh melalui proses kognitif.

Menurut Tampubolon (2008), persepsi adalah gambaran seseorang tentang sesuatu obyek yang menjadi fokus permasalahan yang sedang dihadapi. Jadi dapat disimpulkan bahwa persepsi adalah hasil dari suatu proses pengorganisasian dan penginterpretasian terhadap stimulus yang diterima indera sehingga stimulus tersebut dimengerti dan mempengaruhi tingkah laku selanjutnya.

Dalam penelitian ini, objek yang dipersepsikan yaitu pekerjaan di sektor pertanian padi sawah dan subjek yang mempersepsikan ialah remaja desa. Penelitian ini juga ingin melihat apakah remaja desa akan menekuni pekerjaan di sektor pertanian padi sawah atau tidak. Oleh karena itu, persepsi remaja desa terhadap pekerjaan di sektor pertanian padi sawah ialah proses pengorganisasian dan penginterpretasian yang dilakukan remaja desa terhadap pekerjaan di sektor pertanian padi sawah yang akhirnya dapat mempengaruhi tingkah laku selanjutnya, yakni menekuni pekerjaan di sektor pertanian padi sawah atau tidak.

\section{Faktor Pembentuk Persepsi Remaja Desa terhadap Pekerjaan Di Sektor Pertanian}

Dalam melakukan penilaian dan pemaknaan terhadap suatu objek, terdapat beberapa hal yang mendorong atau mempengaruhi pandangan terhadap objek tersebut. Demikian halnya dengan persepsi remaja desa terhadap pekerjaan di sektor pertanian. Di bawah ini akan dijelaskan beberapa hal yang dapat mempengaruhi pembentukan persepsi remaja desa.

\section{Sosialisasi}

Dalam penelitiannya, Muksin (2007) mengatakan bahwa pemuda (yang seusia dengan remaja) lebih sering berinteraksi dengan temannya. Tingginya hubungan interpersonal pemuda (yang seusia dengan remaja) dengan temannya karena pada fase ini umumnya mereka lebih memiliki kebutuhan perasaan untuk didengarkan dan pencarian jati diri. Hubungan persahabatan sangat kental pada masa usia ini. Dalam penelitiannya Muksin (2007), mengatakan "pemuda memiliki persepsi bahwa mengolah lahan atau sumberdaya lain dinilai belum menjadi kegiatan produktif dan tidak akan banyak menghasilkan uang. Persepsi semacam ini dipengaruhi oleh teman-teman sebaya yang sudah atau sedang bekerja di kota". Jadi jika teman-temannya memiliki pandangan negatif atau positif terhadap suatu pekerjaan,

\footnotetext{
${ }^{1}$ Sumber: http://id.wikipedia.org/wiki/Pekerjaan (diakses pada 14 Februari 2011, pukul 12:49)
} 
maka remaja pun turut memiliki pandangan yang sama agar dapat diterima oleh teman-temannya.

Sosialisasi perkerjaan pertanian bervariasi tergantung dari karakteristik asli daerah pedesaan. Terdapat dorongan dari orang tua agar anak-anaknya mencari pekerjaan yang "lebih baik" dan "lebih menjanjikan" di perkotaan (Muksin 2007). Orang tua memberikan sosialisasi yang kurang tepat terkait pesimisme orang tua atas pekerjaan-pekerjaan yang berkaitan dengan eksplorasi dan budidaya yang memanfaatkan sumberdaya alam. Nilai-nilai tersebut (seperti persepsi) diterima remaja dari orang tua mereka. Oleh karena itu, persepsi remaja mengenai pekerjaan di sektor pertanian juga dipengaruh oleh keluarga. Jika keluarga mendukung dan mensosialisasikan anaknya untuk bekerja di perkotaan (sektor non pertanian), maka hal itu dapat menyebabkan persepsi yang kurang baik terhadap pekerjaan sektor pertanian pada anak. Dengan begitu, dapat dikatakan bahwa pengaruh keluarga juga menentukan persepsi remaja terhadap pekerjaan di sektor pertanian, karena remaja akan menilai suatu pekerjaan yang telah diajarkan oleh orangtuanya semenjak ia masih kecil.

\section{Lahan}

Di pedesaan umumnya mengalami permasalahan yang sama yakni kekurangan lahan dan kepadatan penduduk yang tinggi. Diduga bertambahnya penduduk dengan cepat membuat luasan tanah untuk bekerja di bidang pertanian semakin sempit. Sempitnya lahan pertanian ini diperparah dengan kecenderungan konversi lahan pertanian, bahkan lahan pertanian tersubur untuk pemakaian lain, khususnya di Jawa yang mengalami urbanisasi dan industrialisasi. Usaha di sektor pertanian tak heran lama-kelamaan mulai ditinggalkan dan masyarakat desa mulai beralih ke sektor non pertanian karena merasa situasi dan kondisi alam, dalam hal ini lahan, kurang mendukung untuk memenuhi kebutuhan hidup mereka. Namun menurut hasil penelitian Muksin (2007), dengan banyaknya pemuda yang berpendapat bahwa sumberdaya alam dapat dimanfaatkan untuk kegiatan produktif, maka hal tersebut dapat memotivasi kelompok pemuda untuk menjadikan pemanfaatan lingkungan alam sebagai sumber penghasilan. Dari hal ini dapat disimpulkan bahwa ketersediaan sumberdaya alam, dalam hal ini lahan pertanian, juga mempengaruhi persepsi seseorang untuk menjadikan sektor pertanian sebagai mata pencaharian.

\section{Tingkat Pendidikan}

Tingkat pendidikan formal di desa umumnya rendah, termasuk pendidikan para remajanya juga. Muksin (2007) mengutarakan pendapatnya mengenai pendidikan di pedesaan, yakni tingkat pendidikan formal pemuda desa umumnya rendah karena persepsi terhadap pendidikan formal yang masih kurang positif dan pesimisme pada responden yang juga tersosialisasikan melalui orang tua bahwa tingginya pendidikan tidak menjamin seseorang mendapat pekerjaan yang layak. Pendidikan juga mempengaruhi cara berpikir remaja yang nantinya dapat berperan pula dalam pembentukan persepsi terhadap pekerjaan di sektor pertanian. Dapat dikatakan bahwa semakin rendah tingkat pendidikan yang dapat dicapai, maka remaja menyadari betul semakin kecilnya peluang untuk bekerja di luar sektor pertanian yang secara umum dinilai lebih baik dan bergengsi, serta merasa kemampuan yang dipunya hanya cukup untuk menekuni pekerjaan di sektor pertanian. Begitu pun sebaliknya, remaja yang memiliki pendidikan yang lebih tinggi mempunyai kecenderungan orientasi kerja keluar sektor pertanian.

\section{Pengalaman Pribadi}

Pengalaman masa lalu, sebagai hasil dari proses belajar, akan sangat mempengaruhi bagaimana seseorang mempersepsikan sesuatu. Menurut Karyana (1999) yang dikutip oleh Reza (2007), pengalaman berusaha tani didefinisikan sebagai lamanya petani mengerjakan usaha padi sawah atau usahatani lahan kering lainnya. Lestari (1994) yang dikutip oleh Reza (2007) juga mendefinisikan pengalaman berusaha tani sebagai lamanya petani responden mulai membudidayakan padi sawah. Demikian juga dengan remaja desa, semakin lama bergerak di bidang usahatani, semakin banyak pengetahuan yang ia dapat dari pengalamannya itu. Pengalaman yang dirasakan remaja tentang bagaimana kehidupannya orang tuanya (beserta dirinya sendiri) ketika orang tuanya bekerja di sektor pertanian, baik pengalaman yang menyenangkan maupun tidak, akan menjadi informasi dan bahan dalam pembentukan persepsi remaja tersebut.

\section{Jenis Kelamin}


Selain itu, menurut Tarigan (2004), jenis kelamin juga turut menentukan orientasi kerja pemuda. Pekerjaan pertanian membutuhkan tenaga yang kuat dan dapat merusak penampilan karena ruang kerjanya berada di bawah terik matahari dan kotor sehingga lebih sesuai untuk kaum pria. Pekerjaan pertanian juga lebih banyak ditekuni oleh pria akibat tuntutan sebagai penanggung jawab ekonomi keluarga.

\section{Kerangka Pemikiran}

Perkembangan ekonomi menunjukkan peranan sektor industri dan jasa yang telah meningkat, sedangkan peranan pertanian secara relatif menurun dalam produk nasional. Telah terjadi fenomena penurunan jumlah tenaga kerja di sektor pertanian dari tahun ke tahun, terutama tenaga kerja dari generasi muda.

Remaja merupakan termasuk dalam angkatan kerja generasi muda. Dalam hal ini, remaja desa mempunyai persepsi tersendiri mengenai pekerjaan di sektor pertanian. Pada penelitian ini, sektor pertanian lebih dipersempit menjadi pertanian padi sawah, sesuai dengan komoditas yang paling dominan di daerah lokasi penelitian. Persepsi berhubungan dengan beberapa faktor, yaitu faktor internal dan faktor eksternal. Penelitian ini mengukur faktor internal dan faktor eksternal yang berhubungan dengan persepsi remaja namun dibatasi pada karakteristik tertentu.

Seringkali persepsi dikaitkan dengan tingkat pendidikan, pengalaman pribadi remaja, dan jenis kelamin, dimana semua hal tersebut termasuk dalam karakteristik remaja. Tingkat pendidikan remaja desa yang pada umumnya rendah dapat mempengaruhi cara berpikir remaja terhadap pekerjaan di sektor pertanian yang dianggap tidak memerlukan keterampilan yang tinggi. Pengalaman remaja yang didapat dari pengalamannya sendiri melihat dan membantu pekerjaan orang tua dan masyarakat sekelilingnya yang rata-rata pernah atau masih menggeluti pekerjaan di sektor pertanian, membuat remaja melakukan perbandingan yang akhirnya dapat membentuk persepsi remaja mengenai pekerjaan di sektor pertanian padi sawah. Selain itu, pekerjaan pertanian juga membutuhkan tenaga yang kuat dan dapat merusak penampilan karena ruang kerjanya berada di bawah terik matahari dan kotor sehingga lebih sesuai untuk kaum pria. Pekerjaan pertanian juga lebih banyak ditekuni oleh pria akibat tuntutan sebagai penanggung jawab ekonomi keluarga.

Faktor eksternal juga diduga berhubungan dengan persepsi remaja mengenai pekerjaan di sektor pertanian padi sawah. Faktor eksternal tersebut merupakan karakteristik lingkungan sekitar remaja yang terdiri dari pengaruh status kepemilikan lahan sawah, pengaruh teman-teman sebaya remaja, dan pengaruh dari keluarga. Status kepemilikan lahan sawah orang tua remaja turut berpengaruh terhadap persepsi remaja desa. Ketersediaan lahan sawah, baik itu luas maupun sempit, yang dimiliki orang tua remaja akan mempengaruhi positif atau negatifnya persepsi remaja terhadap pekerjaan di sektor pertanian, khususnya pertanian padi sawah.

Selain itu, pandangan dari teman-teman sebaya mengenai suatu pekerjaan akan sangat berpengaruh bagi anak usia remaja, dimana pada masa usia ini remaja lebih sering berinteraksi dengan temannya, dan hubungan pertemanan dan persahabatan sangat kental. Pengaruh dari orang tua juga berperan dalam pembentukan persepsi remaja desa. Orang tua dan kerabat biasanya melibatkan anak laki-laki untuk mengenal pekerjaan bertani, seperti mengajak ke sawah untuk membantu pekerjaan-pekerjaan di sawah yang ringan. Remaja akan menilai suatu pekerjaan yang telah diajarkan oleh orang tuanya semenjak ia masih kecil. Berdasarkan uraian di atas, dapat dikatakan baik faktor internal maupun faktor eksternal tersebut dapat mempengaruhi pembentukan persepsi remaja desa terhadap pekerjaan di sektor pertanian padi sawah. Persepsi terhadap pekerjaan di sektor pertanian nantinya akan berpengaruh terhadap minat remaja desa untuk menggeluti pekerjaan di sektor pertanian padi sawah.

\section{Hipotesis Penelitian}

Berdasarkan kerangka pemikiran, dapat disusun hipotesis penelitian sebagai berikut:

1. Karakeristik remaja desa berhubungan dengan persepsi remaja desa terhadap pekerjaan di sektor pertanian padi sawah.

2. Karakteristik lingkungan remaja berhubungan dengan persepsi remaja desa terhadap pekerjaan di sektor pertanian padi sawah. 


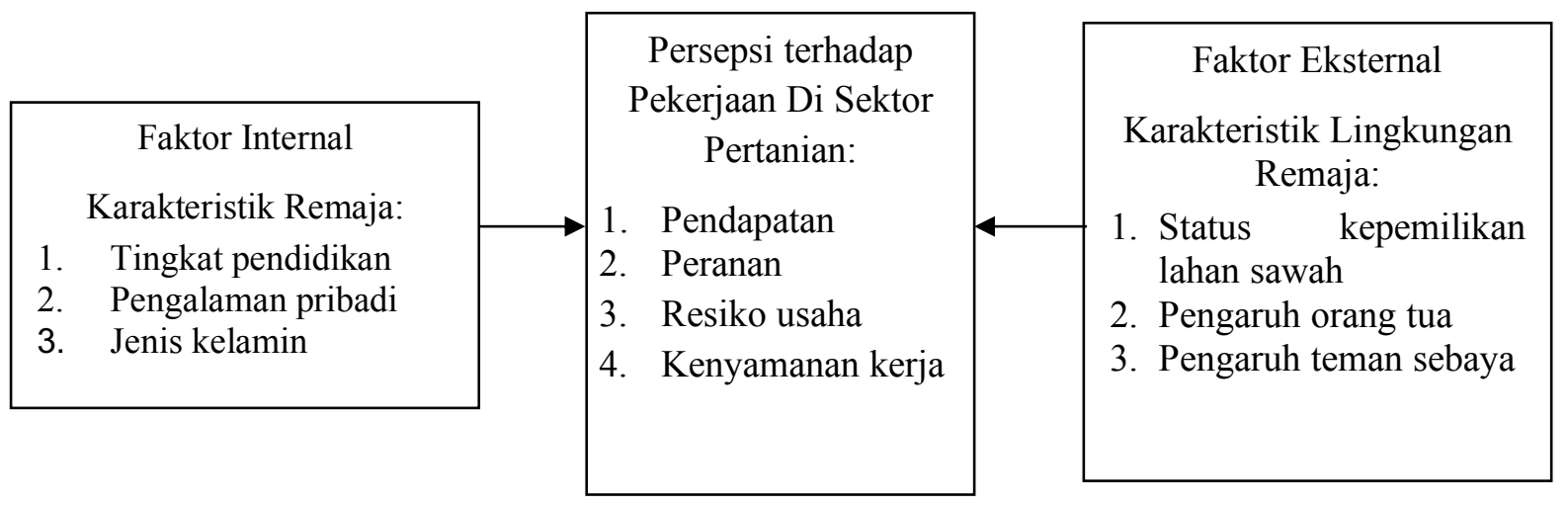

Gambar 1 Kerangka pemikiran

Keterangan:

$\longrightarrow$ berhubungan

\section{PENDEKATAN LAPANGAN}

Penelitian dilaksanakan di Desa Cileungsi, Kecamatan Ciawi, Kabupaten Bogor, Provinsi Jawa Barat. Lokasi penelitian dipilih secara sengaja (purposive). Lokasi tersebut dipilih karena Desa Cileungsi memiliki gapoktan yang aktif dan maju, serta memiliki lahan persawahan yang cukup luas, sehingga didominasi dengan komoditas dari sektor tanaman pangan, yaitu padi sawah.

Metode yang digunakan dalam memperoleh dan menganalisis data adalah metode kuantitatif yang didukung oleh data kualitatif. Metode kuantitatif dilakukan dengan metode survai kepada responden. Sementara data kualitatif diperoleh melalui wawancara kepada informan dan observasi di lapangan. Data kualitatif dalam penelitian ini juga didapatkan dengan wawancara mendalam kepada responden berdasarkan pertanyaan yang terdapat dalam kuesioner maupun di luar kuesioner yang sesuai dengan tujuan penelitian.

Pengambilan sampel responden dalam penelitian ini dilakukan melalui teknik simple random sampling, yaitu sebuah sampel yang diambil sedemikian rupa sehingga tiap unit penelitian atau satuan elementer dari populasi mempunyai kesempatan yang sama untuk dipilih sebagai sampel (Singarimbun dan Effendi 2008). Kriteria responden yang ditetapkan adalah remaja Desa Cileungsi dengan rentang usia 15-20 tahun, belum menikah, dan merupakan anak dari petani padi sawah. Setelah dilakukan pendataan, didapatkan kerangka sampling 155 remaja yang memenuhi kriteria. Kemudian ditentukan sampel penelitian yang berjumlah 40 responden, yang terdiri dari 20 remaja perempuan dan 20 remaja laki-laki. Pengambilan responden tersebut dipilih karena responden yang diambil bersifat homogen, dimana mereka sama-sama sesuai dengan kriteria yang telah ditetapkan.

Pengumpulan data dilakukan dengan mengumpulkan data sekunder dan data primer. Dalam penelitian ini, data sekunder (kuantitatif dan kualitatif) diperoleh dari data kelurahan desa, seperti potensi desa. Data primer kuantitatif dalam penelitian ini, dikumpulkan melalui wawancara terstruktur kepada 40 responden dengan menggunakan kuesioner. Data primer yang diperoleh dari hasil kuesioner diolah secara statistik deskriptif. Statistik deskriptif digunakan untuk menggambarkan atau mendeskripsikan data yang telah terkumpul (Riswar 2012). Selanjutnya data-data tersebut dipindahkan ke dalam Microsoft Excel 2007 yang telah disiapkan. Data-data tersebut diolah menggunakan SPSS 17.0 for Windows. Data yang telah diolah kemudian dilakukan uji korelasi dengan menggunakan Chi Square dan Rank Spearman, untuk mengetahui apakah faktor internal dan eksternal berhubungan dengan persepsi remaja desa terhadap pekerjaan di sektor pertanian padi sawah atau tidak.

Pengujian hubungan antara persepsi mengenai pekerjaan di sektor pertanian (dalam hal pendapatan, peranan, resiko usaha, dan kenyamanan kerja) dengan karakteristik remaja (tingkat pendidikan dan pengalaman pribadi) dianalisis dengan menggunakan Rank Spearman. Sementara itu, untuk variabel karakteristik remaja seperti jenis kelamin dianalisis dengan menggunakan Chi Square. Pengujian hubungan 
antara persepsi mengenai pekerjaan di sektor pertanian (dalam hal pendapatan, peranan, resiko usaha, dan kenyamanan kerja) dengan karakteristik lingkungan remaja (pengaruh orang tua dan pengaruh teman sebaya) dianalisis dengan menggunakan Rank Spearman. Untuk variabel karakteristik lingkungan remaja seperti status kepemilikan lahan sawah dianalisis dengan menggunakan Chi Square.

\section{HASIL DAN PEMBAHASAN}

\section{Karakteristik Remaja Dan Lingkungan Desa Cileungsi}

\section{Faktor Internal Responden Penelitian}

Faktor internal dalam penelitian ini merupakan karakteristik remaja yang terdiri dari tingkat pendidikan, pengalaman pribadi bertani, dan jenis kelamin. Berikut ini akan dibahas satu-persatu karakteritik remaja, dimulai dari tingkat pendidikan. Remaja dalam penelitian ini memiliki tingkat pendidikan yang beragam. Tingkat pendidikan terakhir remaja dalam penelitian ini adalah SD, SLTP, SMA, dan Perguruan Tinggi. Sebagian besar remaja memiliki tingkat pendidikan hingga SD, yaitu sebanyak 17 orang atau 42,5 persen dari total seluruhnya. Selebihnya terdapat 15 orang dengan tingkat pendidikan hingga SMP, 7 orang dengan tingkat pendidikan hingga SMA, dan hanya 1 orang yang tingkat pendidikannya mencapai Perguruan Tinggi.

Berdasarkan data monografi Desa Cileungsi, secara keseluruhan tingkat pendidikan masyarakat Desa Cileungsi tergolong rendah, yaitu mencapai pendidikan hingga tingkat SD. Tingkat pendapatan yang relatif rendah dan kesadaran akan pentingnya pendidikan masih kurang, sehingga banyak dari penduduk Desa Cileungsi, khususnya remaja, yang hanya menamatkan sekolah sampai SD saja. Hal ini sesuai dengan hasil penelitian Muksin (2007) yang mengutarakan mengenai pendidikan di pedesaan, yakni tingkat pendidikan formal pemuda desa umumnya rendah karena persepsi terhadap pendidikan formal yang masih kurang positif dan pesimisme pada responden yang juga tersosialisasikan melalui orang tua bahwa tingginya pendidikan tidak menjamin seseorang mendapat pekerjaan yang layak.

Pengalaman pribadi remaja dalam bertani, dilihat dari lamanya remaja terlibat dalam pekerjaan pertanian padi sawah dan bagaimana pengalaman yang didapat. Pengalaman pribadi remaja dikategorikan menjadi 3 , yaitu pengalaman yang negatif, netral, dan positif. Terlihat bahwa lebih dari separuh responden mempunyai pengalaman pribadi yang negatif terhadap pekerjaan di sektor pertanian padi sawah (52,5 persen). Hanya terdapat 10 persen atau 4 orang yang mempunyai pengalaman positif dengan bertani, sisanya adalah remaja dengan pengalaman yang netral.

Sebagian besar remaja mengaku jarang membantu orang tuanya dalam bertani padi sawah. Ada pun kegiatan yang mereka lakukan lebih banyak membantu pada saat pemanenan sehingga tidak banyak kegiatan bertani lainnya yang mereka ketahui cara melakukannya.

Jarangnya remaja terlibat dalam kegiatankegiatan bertani lainnya disebabkan oleh kerumitan akan kegiatan bertani yang dirasakan para remaja. Melakukan pengolahan tanah, pemupukan, dan penanaman dirasa sangat menyusahkan bagi para remaja. Terdapat remaja (MRD 15 tahun) yang mengatakan bahwa penanaman dan perawatan tanaman tidak sebanding dengan hasil (panen) yang didapat. Kerumitan yang dirasakan para remaja tersebut mengurangi semangat mereka untuk terlibat dalam kegiatan bertani. Meskipun sebagian besar remaja turut juga membantu pada waktu pemanenan, namun hal itu tidak membuat pandangan mereka menjadi positif terhadap pengalaman mereka dalam bertani. Remaja yang lain (RJL 20 tahun) juga mengeluhkan akan lamanya masa panen itu datang. Selain itu, dalam pengolahan tanah, remaja harus mencangkul tanah sehingga hal itu dirasa berat oleh remaja tersebut.

Bagi remaja yang punya pengalaman positif terhadap bertani, rata-rata mereka sudah cukup lama terlibat dalam kegiatan bertani sehingga semakin banyak pengetahuan yang mereka dapat dari pengalamannya itu. Pengalaman yang dirasakan remaja sendiri tentang bagaimana kehidupannya orang tuanya (beserta dirinya sendiri) ketika orang tuanya bekerja di sektor pertanian, baik pengalaman yang menyenangkan maupun yang tidak, akan menjadi informasi dan menjadi bahan dalam pembentukan persepsi remaja tersebut.

Responden dalam penelitian ini ialah 40 remaja dengan 20 orang jenis kelamin laki-laki dan 20 orang jenis kelamin perempuan. Jumlah laki-laki 
dan perempuan sengaja dibuat sama oleh peneliti agar perbandingannya seimbang. Dibandingkan remaja perempuan, remaja laki-laki lebih sering turun ke sawah untuk bertani. Remaja perempuan umumnya hanya membantu dalam membawakan makanan saja untuk orang tua mereka pada siang hari.

\section{Faktor Eksternal Responden Penelitian}

Faktor eksternal dalam penelitian ini merupakan karakteristik lingkungan remaja yang terdiri dari status kepemilikan lahan sawah, pengaruh orang tua, dan pengaruh teman sebaya. Dalam subbab ini akan dijelaskan mengenai gambaran umum kepemilikan lahan sawah dari keluarga remaja tersebut dan gambaran umum mengenai lingkungan sosial remaja yang lebih menekankan kepada hubungan interaksi manusia, yaitu hubungan remaja dengan orang tua dan dengan teman-teman sebayanya.

Status kepemilikan lahan sawah adalah status kepunyaan lahan sawah dari orang tua remaja desa yang bekerja sebagai petani. Status kepemilikan lahan sawah dikategorikan menjadi 2 , yaitu punya lahan sawah dan tidak punya lahan sawah. Dalam penelitian ini sebagian besar adalah remaja yang orang tuanya tidak memiliki lawah sawah (buruh tani), yaitu sebanyak 24 orang.

Menurut monografi Desa Cileungsi 2012, jumlah penduduk Desa Cileungsi yang bermata pencaharian buruh tani (801 orang) memang lebih banyak daripada jumlah petani (616 orang). Semakin menurunnya jumlah petani disebabkan oleh meningkatnya jumlah petani yang menjual lahan sawahnya untuk memenuhi kebutuhan hidup keluarganya lalu memilih bekerja di bidang non pertanian.

Pengaruh orang tua terhadap remaja dalam hal pertanian, dapat dilihat dari pengenalan tentang hal-hal pertanian dan motivasi bekerja (dorongan dan arahan agar remaja bekerja di sektor pertanian atau non pertanian). Pengaruh orang tua dikategorikan menjadi dua, yaitu pengaruh yang lemah dan pengaruh yang kuat.

Berdasarkan hasil penelitian, terlihat bahwa sebagian besar orang tua remaja memiliki kekuatan yang lemah dalam mempengaruhi remaja untuk bertani (52,5 persen). Mereka memang sudah mengenalkan pertanian pada anaknya dari sejak dini, namun hanya untuk membantu mereka saja, bukan berharap anak mereka kelak akan mengikuti jejak mereka sebagai petani. Para orang tua yang justru lebih mendorong anak-anaknya bekerja di perkotaan atau bekerja di sektor non pertanian, yang dianggap lebih menghasilkan. Hal ini sesuai dengan pendapat Daulay (2006) yang mengatakan perubahan sosialisasi nilai kerja salah satunya dipengaruhi oleh munculnya kesempatan-kesempatan bekerja di luar sektor pertanian. Masuknya lapangan pekerjaan non pertanian di desa menjadi bahan pertimbangan bagi para orang tua, yang kemudian menyuruh anak-anaknya untuk bekerja di luar pertanian.

Dalam hal pengaruh dari teman-teman sebaya, sebagian besar teman-teman sebaya remaja memiliki pengaruh yang kuat terhadap remaja mengenai pekerjaan di sektor pertanian. Pada Gambar 7 terlihat sebanyak 70 persen atau 28 orang remaja mempunyai pengaruh teman sebaya yang kuat, sedangkan pengaruh teman sebaya yang lemah mencapai 30 persen atau 12 orang. Salah seorang responden menyatakan:
"Penerimaan dari teman-teman penting sih buat saya. Soalnya tiap pulang sekolah pasti selalu bareng sama teman-teman, pergi kemana-mana lebih sering sama teman- teman. Jadi kalau beda pendapat dari teman- teman tuh rasanya sangat ga nyaman, seperti dimusuhin aja." (WWN 16 tahun)

Hubungan persahabatan sangat kental pada masa usia ini. Begitu pun dengan remaja di Desa Cileungsi ini yang sebagian besar merasa butuh pandangan dari teman-temannya, termasuk dalam hal pekerjaan. Pengaruh yang diberikan teman sebaya remaja dapat mempengaruhi penilaian remaja terhadap pekerjaan di sektor pertanian. Jadi jika teman-temannya memiliki pandangan negatif atau positif terhadap suatu pekerjaan, maka remaja pun turut memiliki pandangan yang sama agar dapat diterima oleh teman-temannya. Oleh karena itu, dapat dikatakan persepsi remaja terhadap pekerjaan sektor pertanian turut dipengaruhi juga oleh teman-teman sebayanya.

\section{Persepsi Remaja terhadap Pekerjaan di Sektor Pertanian Padi Sawah}

\section{Persepsi tentang Pendapatan}

Penelitian ini bertujuan untuk mengidentifikasi persepsi remaja Desa Cileungsi terhadap pekerjaan di sektor pertanian padi sawah. 
Persepsi adalah gambaran seseorang tentang sesuatu obyek yang menjadi fokus permasalahan yang sedang dihadapi (Tampubolon 2008). Dalam penelitian ini, objek yang dipersepsikan yaitu pekerjaan di sektor pertanian padi sawah dan subjek yang mempersepsikan ialah remaja desa. Berikut ini akan dijelaskan mengenai persepsi remaja tentang pendapatan, peranan, resiko usaha, dan kenyamanan kerja pada pekerjaan di sektor pertanian padi sawah secara keseluruhan.

Selama ini memang banyak anggapan bahwa mengolah lahan atau sumberdaya lain dinilai belum menjadi kegiatan produktif dan tidak akan banyak menghasilkan uang (Muksin 2007), namun hasil penelitian menunjukkan sebagian besar remaja Desa Cileungsi justru memiliki persepsi yang positif tentang pendapatan pada pekerjaan di sektor pertanian padi sawah, yakni 72,5 persen atau sama dengan 29 orang. Hal ini dikarenakan sebagian besar remaja Desa Cileungsi yang berpendapat bahwa bekerja sebagai petani cukup untuk memenuhi kebutuhan hidup sehari-hari (pangan, sandang, dan papan) serta cukup untuk membiayai sekolah.

Dalam kuesiner penelitian diajukan lima pernyataan terkait persepsi remaja mengenai pendapatan dalam bertani. Masing-masing pernyataan diberi skor yang sesuai dengan apa yang dirasakan remaja. Kelima pernyataan tersebut ialah:

1. Bekerja sebagai petani, dapat menghasilkan uang yang cukup untuk memenuhi kebutuhan hidup sehari-hari (pangan, sandang, dan papan).

2. Bekerja sebagai petani, dapat menghasilkan uang yang cukup untuk membiayai sekolah.

3. Bekerja sebagai petani, dapat menghasilkan uang yang memungkinkan untuk di tabung.

4. Kondisi cuaca dan musim yang kurang baik, tidak akan terlalu mempengaruhi penghasilan seorang petani.

5. Bekerja sebagai petani, dapat menghasilkan uang yang lama-kelamaan akan bertambah banyak.

Dari kelima pernyataan tersebut, rata-rata remaja memberi skor tinggi pada pernyataan pertama dan kedua yaitu bekerja sebagai petani dapat menghasilkan uang yang cukup untuk memenuhi kebutuhan hidup sehari-hari (pangan, sandang, dan papan) serta dapat menghasilkan uang yang cukup untuk membiayai sekolah. Hal ini menunjukkan bahwa bagi remaja, pekerjaan di sektor pertanian padi sawah masih dapat memenuhi kebutuhan-kebutuhan mereka, minimal untuk memenuhi kebutuhan dasar (pangan, sandang, dan papan).

Walgito (2010) menerangkan bahwa pengalaman seseorang berperan dalam seseorang mempersepsi. Selain itu Walgito (2010) juga menambahkan persepsi itu tidak hanya ditentukan atau dipengaruhi oleh stimulus secar objektif, tetapi juga akan ditentukan atau dipengaruhi oleh keadaan diri orang yang mempersepsi. Hal ini juga yang dialami remaja Desa Cileungsi yang menurut pengalamannya, uang hasil bertani padi sawah itu (sebagai stimuli awal) dapat memenuhi kebutuhan hidup seharihari (pangan, sandang, dan papan) serta cukup untuk membiayai sekolah (keadaan diri orang yang mempersepsi) sehingga terbentuklah persepsi yang positif.

\section{Persepsi tentang Peranan}

Berdasarkan hasil penelitian, sebagian besar remaja Desa Cileungsi memiliki persepsi yang positif tentang peranan pada pekerjaan di sektor pertanian padi sawah, yaitu 75 persen atau setara dengan 30 orang. Latifah (2007) menjelaskan proses terjadinya persepsi yang dimulai dari objek yang menimbulkan stimulus, kemudian stimulus yang mengenai alat indera diteruskan oleh syaraf sensoris ke otak dan terjadilah proses pengamatan yang dipengaruhi oleh faktor pengalaman, proses belajar, cakrawala dan pengetahuan yang dimiliki orang tersebut. Remaja Desa Cileungsi juga tentunya mengetahui informasi mengenai peranan pertanian padi sawah (yang merupakan objek stimuli) yang diperoleh dari pengalaman pribadinya dan pengetahuan yang berasal dari pendidikannya (faktor internal) serta proses belajar atau sosialisasi lingkungan sekitar (faktor eksternal) sehingga terciptalah suatu persepsi (dalam hal ini persepsi yang positif).

Terdapat lima pernyataan terkait persepsi remaja mengenai peranan dalam bertani yang terdapat pada kuesioner penelitian, yaitu:

1. Sektor pertanian merupakan sumber pemasukan yang diperlukan untuk pembangunan dan sumber pendapatan penduduk yang hidup di pedesaan.

2. Kegiatan ekonomi di sektor pertanian padi sawah yang menghasilkan produk dapat 
memenuhi kebutuhan pangan untuk keperluan sendiri (subsistence).

3. Kegiatan ekonomi di sektor pertanian padi sawah yang menghasilkan produk dapat memenuhi kebutuhan pasar di luar daerah (desa).

4. Sektor pertanian padi sawah dapat menampung tenaga kerja yang banyak dan tidak memerlukan keterampilan yang khusus.

5. Sektor pertanian padi sawah menghasilkan produk pertanian yang berguna sebagai bahan baku pada sektor industri.

Sebagian besar remaja menjawab bahwa sektor pertanian berperan dalam hal sumber pendapatan penduduk yang hidup di pedesaan dan dapat menghasilkan produk yang dapat memenuhi kebutuhan pangan untuk keperluan sendiri (subsistence) maupun kebutuhan pasar di luar daerah (desa). Oleh sebab itu dapat dikatakan bahwa persepsi sebagian besar remaja Desa Cileungsi mengenai peranan pekerjaan di sektor pertanian padi sawah ialah positif.

\section{Persepsi tentang Resiko Usaha}

Hasil penelitian menunjukkan sebagian besar remaja Desa Cileungsi memiliki persepsi yang negatif tentang resiko usaha pada pekerjaan di sektor pertanian padi sawah, yakni 90 persen atau sama dengan 36 orang. Pada kuesioner penelitian terdapat lima pernyataan terkait resiko usaha dalam bertani yang harus diberi skor oleh remaja sesuai dengan apa yang mereka rasakan, yakni:

1. Pekerjaan di sektor pertanian padi sawah dapat beresiko ketidakstabilan harga di pasaran.

2. Pekerjaan di sektor pertanian padi sawah dapat beresiko mahalnya biaya pengadaan sarana produksi.

3. Pekerjaan di sektor pertanian padi sawah dapat beresiko gagal panen (bergantung pada cuaca).

4. Pekerjaan di sektor pertanian padi sawah dapat beresiko terserang hama tanaman.

5. Pekerjaan di sektor pertanian padi sawah berarti perputaran uangnya lama (menunggu masa panen dulu).

Sebagian besar remaja Desa Cileungsi berpendapat bahwa resiko usaha dalam bertani padi sawah yang paling mereka rasakan ialah pekerjaan di sektor pertanian padi sawah bergantung pada cuaca dan beresiko terserang hama tanaman.

Robbins (2002) yang dikutip oleh Mastari (2012) mengatakan bahwa munculnya persepsi negatif seseorang disebabkan adanya ketidakpuasan individu terhadap objek yang menjadi sumber persepsinya. Dalam hal ini, remaja Desa Cileungsi memiliki persepsi negatif karena ketidakpuasan remaja terhadap resiko usaha dalam bertani. Para remaja merasa selama ini belum ada solusi untuk menanggulangi masalah resiko usaha di bidang pertanian padi sawah. Dengan kata lain, resiko usaha dari pekerjaan di sektor pertanian padi sawah tersebut telah membentuk persepsi yang negatif pada remaja Desa Cileungsi.

\section{Persepsi tentang Kenyamanan Kerja}

Berdasarkan Tabel 6, sebagian besar remaja Desa Cileungsi memiliki persepsi yang negatif tentang kenyamanan kerja pada pekerjaan di sektor pertanian padi sawah, yaitu 62,5 persen atau setara dengan 25 orang. Untuk mengetahui persepsi remaja terhadap kenyamanan kerja dalam bertani, diajukan lima pernyataan dalam kuesioner yang terkait dengan kenyamanan kerja dalam bertani, yang harus diberi skor sesuai dengan apa yang mereka rasakan. Pernyataanpernyataan itu adalah:

1. Jam kerja sebagai petani lebih panjang/banyak dari pada jam kerja orang yang bekerja di luar sektor pertanian.

2. Bekerja sebagai petani berarti bekerja di tempat yang terbuka dan terkena matahari langsung.

3. Bekerja sebagai petani berarti melakukan pekerjaan yang sangat berat dan melelahkan.

4. Bekerja sebagai petani berarti melakukan pekerjaan yang kotor dan berlumpur.

5. Bekerja sebagai petani akan merusak penampilan fisik.

Dari kelima pernyataan tersebut, skor tertinggi banyak diberikan pada pernyataan kedua, ketiga, dan keempat. Bagi para remaja, bekerja sebagai petani padi sawah berarti melakukan serangkaian kegiatan seperti pengolahan tanah, pemupukan, penanaman, sampai dengan pemanenan, yang bertempat di ruang terbuka dan terkena matahari langsung. Bekerja sebagai petani padi sawah juga berarti melakukan pekerjaan yang kotor dan berlumpur serta melelahkan, seperti mencangkul. 
Dari hal-hal tersebut dapat disimpulkan bahwa ruang kerja yang terbuka dan terkena matahari langsung, serta kegiatan fisik yang cukup berat membuat para remaja Desa Cileungsi menjadi tidak nyaman dan akhirnya membentuk persepsi yang negatif terhadap pekerjaan di sektor pertanian padi sawah.

\section{Persepsi Remaja menurut Faktor Internal Remaja}

Penelitian ini bertujuan untuk mengetahui faktorfaktor yang berhubungan dengan persepsi remaja Desa Cileungsi terhadap pekerjaan di sektor pertanian padi sawah. Faktor internal yang diuji hubungannya dengan persepsi remaja terhadap pekerjaan di sektor pertanian padi sawah, yaitu karakteristik remaja. Persepsi remaja (dalam hal pendapatan, peranan, resiko usaha, dan kenyamanan kerja) diuji hubungannya dengan 3 karakteristik remaja, yaitu tingkat pendidikan, pengalaman pribadi, dan jenis kelamin. Pengujian hubungan dilakukan dengan menggunakan Rank Spearman dan Chi Square.

Berdasarkan hasil uji tersebut, terdapat dua variabel pada karakteristik remaja yang berhubungan nyata dengan persepsi remaja terhadap pekerjaan di sektor pertanian padi sawah. Hubungan nyata dapat ditunjukkan pada variabel jenis kelamin dengan persepsi remaja dalam hal peranan pertanian dan variabel tingkat pendidikan dengan persepsi remaja dalam hal kenyamanan kerja.

\section{Hubungan antara Persepsi tentang Pendapatan dengan Tingkat Pendidikan}

Hasil pengujian hipotesis hubungan antara persepsi tentang pendapatan dengan tingkat pendidikan ialah tidak terdapat hubungan yang nyata. Hasil uji tersebut menyatakan angka yang didapat dengan menggunakan analisis data Rank Spearman, yaitu nilai signifikan yang diperoleh sebesar .230. Nilai ini melebihi taraf nyata sebesar 0.05 sehingga dapat dikatakan tidak terdapat hubungan antara persepsi tentang pendapatan dengan tingkat pendidikan. Hal ini berarti tidak terdapat perbedaan persepsi antara remaja yang berpendidikan sampai SD, SMP, SMA, maupun Perguruan Tinggi mengenai pendapatan petani. Hubungan antara persepsi tentang pendapatan dengan tingkat pendidikan menunjukkan nilai korelasi sebesar -.194. Nilai negatif yang terdapat pada korelasi tidak menunjukkan hubungan yang berbanding lurus.

\section{Hubungan antara Persepsi tentang Pendapatan dengan Pengalaman Pribadi}

Hasil pengujian hipotesis hubungan antara persepsi tentang pendapatan dengan pengalaman pribadi ialah tidak terdapat hubungan yang nyata. Berdasarkan hasil uji tersebut, angka yang didapat dengan menggunakan analisis data Rank Spearman yaitu nilai signifikan sebesar .834 dan nilai korelasi yang diperoleh sebesar -.034. Nilai ini menunjukkan besaran yang lebih besar dari nilai $p$-value yaitu 0.05 . Berdasarkan hal tersebut, dapat disimpulkan bahwa baik remaja yang mempunyai pengalaman pribadi positif, netral, maupun negatif dalam hal bertani, tidak berbeda dalam hal persepsi tentang pendapatan petani. Mereka merasa bahwa dengan bertani pun masih cukup untuk memenuhi kebutuhan sehari-hari dan membiayai sekolah. Bahkan bagi remaja yang punya pengalaman negatif pun dalam bertani masih berpersepsi positif terhadap pendapatan petani. Seperti misalnya remaja yang merasa mengolah tanah dan menanam padi itu sulit (MRD 15 tahun), namun tetap mengakui bahwa dengan bertani pun cukup untuk memenuhi kebutuhan sehari-hari dan membiayai sekolahnya.

\section{Hubungan antara Persepsi tentang Pendapatan dengan Jenis Kelamin}

Hasil pengujian hipotesis antara persepsi tentang pendapatan dengan jenis kelamin ialah tidak terdapat hubungan yang nyata. Berdasarkan hasil uji, angka yang didapat dengan menggunakan analisis data Chi Square menunjukkan bahwa nilai Asymp. Sig (2 sided) yang diperoleh adalah .059. Nilai ini menunjukkan besaran yang lebih besar dari nilai $p$-value yaitu 0.05 . Hal tersebut berarti baik remaja laki-laki maupun perempuan, tidak terdapat perbedaan persepsi terhadap pendapatan dalam bertani.

\section{Hubungan antara Persepsi tentang Peranan dengan Tingkat Pendidikan}

Hasil pengujian hipotesis hubungan antara persepsi tentang peranan dengan tingkat pendidikan ialah tidak terdapat hubungan yang nyata. Hasil uji tersebut menunjukkan hasil nilai signifikan sebesar .163 dan nilai korelasinya sebesar -.225 . Nilai ini melebihi taraf nyata sebesar 0.05 sehingga dapat dikatakan tidak terdapat hubungan antara persepsi tentang peranan dengan tingkat pendidikan. Berdasarkan hal tersebut, dapat disimpulkan bahwa tidak 
terdapat perbedaan persepsi antara remaja yang berpendidikan sampai SD, SMP, SMA, maupun Perguruan Tinggi mengenai peranan sektor pertanian. Hal ini tidak sejalan dengan hasil penelitian Muksin (2007) yang menyatakan bahwa semakin rendah tingkat pendidikan yang dapat dicapai, maka remaja menyadari betul semakin kecilnya peluang untuk bekerja di luar sektor pertanian yang secara umum dinilai lebih baik dan bergengsi, serta merasa kemampuan yang dipunya hanya cukup untuk menekuni pekerjaan di sektor pertanian. Dengan begitu, sektor pertanian dianggap berperan dalam menampung tenaga kerja yang banyak dan tidak memerlukan keterampilan yang khusus, termasuk juga remaja dengan tingkat pendidikan yang rendah. Selain itu, remaja dengan tamatan dari SD sampai Perguruan Tinggi juga sama-sama setuju akan peranan pertanian sebagai pemasok kebutuhan pangan keluarga sendiri maupun kebutuhan pasar.

\section{Hubungan antara Persepsi tentang Peranan dengan Pengalaman Pribadi}

Hasil pengujian hipotesis hubungan antara persepsi tentang peranan dengan pengalaman pribadi ialah tidak terdapat hubungan yang nyata. Berdasarkan hasil uji, angka yang didapat dengan menggunakan analisis data Rank Spearman yaitu nilai signifikan sebesar .344 dan nilai korelasinya yang diperoleh sebesar -.154. Dapat disimpulkan bahwa baik remaja yang mempunyai pengalaman pribadi positif, netral, maupun negatif dalam hal bertani, tidak berbeda dalam hal persepsi tentang peranan sektor pertanian. Bagi remaja desa (termasuk remaja dengan pengalaman pribadi yang negatif), pertanian merupakan sumber pendapatan penduduk yang hidup di pedesaan. Meskipun sebagian remaja ada yang merasa pekerjaan di sektor pertanian itu rumit dilakukan, tetapi sebagian besar remaja tetap berpendapat bahwa dengan bertani padi sawah, maka keluarga mereka dapat menghasilkan kebutuhan pangan minimal untuk keluarga mereka sendiri.

\section{Hubungan antara Persepsi tentang Peranan dengan Jenis Kelamin}

Hasil pengujian hipotesis antara persepsi tentang peranan dengan jenis kelamin ialah terdapat hubungan yang nyata. Berdasarkan hasil uji, angka yang didapat dengan menggunakan analisis data Chi Square menunjukkan bahwa nilai Asymp. Sig (2 sided) yang diperoleh adalah .048. Nilai ini menunjukkan besaran yang lebih kecil dari nilai $p$-value yaitu 0.05 . Berdasarkan hal tersebut, dapat disimpulkan bahwa remaja laki-laki dan perempuan memiliki persepsi yang berbeda dalam hal peranan sektor pertanian. Remaja laki-laki lebih sering turun ke sawah untuk melakukan aktivitas pertanian daripada remaja perempuan, seperti menggarap sawah, tandur (menanam benih padi), memupuk, hingga memanen. Hal ini membuat lebih banyak remaja laki-laki yang merasakan sendiri peranan bertani dalam hidup mereka, yaitu untuk memenuhi kebutuhan pangan sendiri maupun untuk memenuhi kebutuhan pasar di luar desa. Sebagaimana dijelaskan juga oleh salah satu responden remaja laki-laki (HHM 19 tahun) yang berpendapat bahwa dengan kehadiran petani, maka bahan pangan pun akan terus diproduksi, sehingga kebutuhan pangan keluarga sendiri maupun kebutuhan pasar dapat terpenuhi. Lain lagi dengan jawaban salah satu responden remaja perempuan (SHL 15 tahun) yang lebih banyak menjawab tidak tahu akan peranan-peranan pekerjaan pertanian padi sawah. Oleh karena itu dapat dikatakan bahwa persepsi remaja laki-laki dan perempuan memiliki perbedaan dalam hal peranan sektor pertanian.

\section{Hubungan antara Persepsi tentang Resiko Usaha dengan Tingkat Pendidikan}

Hasil pengujian hipotesis hubungan antara persepsi tentang resiko usaha dengan tingkat pendidikan ialah tidak terdapat hubungan yang nyata. Hasil uji tersebut menunjukkan hasil nilai signifikan sebesar .822 dan nilai korelasinya sebesar -.037. Nilai ini melebihi taraf nyata sebesar 0.05 sehingga dapat dikatakan tidak terdapat hubungan antara persepsi tentang peranan dengan tingkat pendidikan. Dapat disimpulkan bahwa tidak terdapat perbedaan persepsi antara remaja yang berpendidikan sampai SD, SMP, SMA, maupun Perguruan Tinggi terhadap resiko usaha dalam sektor pertanian. Hampir semua remaja berpandangan negatif terhadap resiko usaha bertani. Mereka merasa, bekerja dalam bidang sektor pertanian padi sawah beresiko rentannya tanaman padi terhadap hama.

\section{Hubungan antara Persepsi tentang Resiko Usaha dengan Pengalaman Pribadi}

Hasil pengujian hipotesis hubungan antara persepsi tentang resiko usaha dengan pengalaman pribadi ialah tidak terdapat hubungan yang nyata. Berdasarkan hasil uji, angka yang didapat dengan 
menggunakan analisis data Rank Spearman yaitu nilai signifikan sebesar .066 dan nilai korelasinya yang diperoleh sebesar -.293. Nilai signifikan yang melebihi taraf nyata (0.05) menandakan tidak terdapat hubungan antara persepsi tentang resiko usaha di sektor pertanian dengan pengalaman pribadi remaja. Remaja dengan pengalaman pribadi negatif, netral, maupun positif dalam hal bertani, tidak berbeda dalam hal persepsi tentang resiko usaha sektor pertanian. Hampir seluruh remaja sepakat bahwa bertani padi sawah mempunyai resiko gagal panen dan terserang hama tanaman.

\section{Hubungan antara Persepsi tentang Resiko Usaha dengan Jenis Kelamin}

Hasil pengujian hipotesis antara persepsi tentang resiko usaha dengan jenis kelamin ialah tidak terdapat hubungan yang nyata. Berdasarkan hasil uji, angka yang didapat dengan menggunakan analisis data Chi Square menunjukkan bahwa nilai Asymp. Sig (2 sided) yang diperoleh adalah .278. Nilai ini menunjukkan besaran yang lebih besar dari nilai $p$-value yaitu 0.05 . Hal tersebut berarti baik remaja laki-laki maupun perempuan, tidak terdapat perbedaan persepsi terhadap resiko usaha dalam bertani. Meskipun lebih banyak remaja laki-laki yang turun langsung ke sawah, tetapi tak membuat persepsi mereka tentang resiko usaha terhadap pertanian padi sawah menjadi positif.

\section{Hubungan antara Persepsi tentang Kenyamanan Kerja dengan Tingkat Pendidikan}

Hasil pengujian hipotesis hubungan antara persepsi tentang kenyamanan kerja dengan tingkat pendidikan ialah terdapat hubungan yang nyata. Hasil uji menunjukkan nilai signifikan sebesar .002 dan hasil nilai korelasinya sebesar .476. Nilai ini menunjukkan besaran yang lebih kecil dari nilai $p$-value yaitu 0.05 sehingga dapat dikatakan terdapat hubungan antara persepsi tentang kenyamanan kerja dengan tingkat pendidikan. Berdasarkan hal tersebut, dapat disimpulkan bahwa remaja yang berpendidikan sampai SD, SMP, SMA, maupun Perguruan Tinggi memiliki persepsi yang berbeda-beda dalam hal kenyamanan kerja di sektor pertanian. Berdasarkan kriteria pengukuran koefisien korelasi, maka nilai korelasi -.476 termasuk memiliki keeratan hubungan yang sedang. Nilai negatif yang terdapat pada korelasi menunjukkan hubungan yang tidak berbanding lurus. Hal ini berarti, semakin tinggi tingkat pendidikan yang dicapai oleh remaja, maka persepsi remaja dalam hal kenyamanan kerja di sektor pertanian pun makin negatif. Seperti halnya salah satu responden remaja yang pendidikan terakhirnya mencapai SMA (MKL 18 tahun) memberi skor tertinggi pada empat pernyataan di dalam kuesioner penelitian, yang terkait dengan persepsi terhadap kenyamanan kerja di sektor pertanian. MKL (18 tahun) merasa jam kerja sebagai petani lebih panjang daripada jam kerja orang yang bekerja di luar sektor pertanian. MKL (18 tahun) berpendapat jika bertani berarti bekerja di tempat yang kotor berlumpur dan terkena matahari langsung. Selain itu, MKL (18 tahun) juga menganggap bertani sebagai pekerjaan yang sangat berat dan melelahkan.

Semakin rendah tingkat pendidikan yang dapat dicapai, maka remaja menyadari betul semakin kecilnya peluang untuk bekerja di luar sektor pertanian yang secara umum dinilai lebih baik dan bergengsi, serta merasa kemampuan yang dipunyai hanya cukup untuk menekuni pekerjaan di sektor pertanian (Muksin 2007), oleh karena itu remaja tersebut tidak mempermasalahkan kenyamanan kerja di sektor pertanian. Sebagai contoh, salah seorang remaja yang pendidikan terakhirnya mencapai SD (MHD 18 tahun), pada kuesioner penelitian memberi jawaban "sangat tidak sesuai" pada pernyataan "Jam kerja sebagai petani lebih panjang/banyak dari pada jam kerja orang yang bekerja di luar sektor pertanian". MHD (18 tahun) juga memberikan skor yang rendah pada beberapa pernyataan mengenai kenyamanan kerja di sektor pertanian, seperti "Bekerja sebagai petani berarti melakukan pekerjaan yang sangat berat dan melelahkan" dan "Bekerja sebagai petani akan merusak penampilan fisik." Oleh karena itu, dapat disimpulkan bahwa tingginya pendidikan yang dapat dicapai remaja memiliki hubungan dan bernilai negatif dengan persepsi remaja terhadap kenyamanan kerja di sektor pertanian.

\section{Hubungan antara Persepsi tentang Kenyamanan Kerja dengan Pengalaman Pribadi}

Hasil pengujian hipotesis hubungan antara persepsi tentang kenyamanan kerja dengan pengalaman pribadi ialah tidak terdapat hubungan yang nyata. Berdasarkan hasil uji, angka yang didapat dengan menggunakan analisis data Rank Spearman yaitu nilai signifikan 
sebesar .326 dan nilai korelasinya yang diperoleh sebesar -.159. Nilai signifikan yang melebihi taraf nyata $(0.05)$ menandakan tidak terdapat hubungan antara persepsi tentang kenyamanan kerja di sektor pertanian dengan pengalaman pribadi remaja. Baik remaja yang mempunyai pengalaman pribadi positif, netral, maupun negatif, berpendapat bahwa bertani padi sawah itu merupakan pekerjaan yang sangat melelahkan. Meski ada remaja yang merasa bertani padi sawah itu menyenangkan, tetapi pada kenyataannya mereka tetap merasa bertani padi sawah itu cukup berat karena melakukan aktivitas yang cukup berat, salah satunya ialah mencangkul.

\section{Hubungan antara Persepsi tentang Kenyamanan Kerja dengan Jenis Kelamin}

Hasil pengujian hipotesis antara persepsi tentang kenyamanan kerja dengan jenis kelamin ialah tidak terdapat hubungan yang nyata. Berdasarkan hasil uji, angka yang didapat dengan menggunakan analisis data Chi Square menunjukkan bahwa nilai Asymp. Sig (2 sided) yang diperoleh adalah .344. Nilai ini menunjukkan besaran yang lebih besar dari nilai $p$-value yaitu 0.05 . Dapat disimpulkan bahwa baik remaja laki-laki maupun perempuan, tidak terdapat perbedaan persepsi terhadap kenyamanan kerja dalam bertani. Tarigan (2004) berpendapat bahwa jenis kelamin juga turut menentukan orientasi kerja pemuda. Pekerjaan pertanian lebih banyak ditekuni oleh pria akibat tuntutan sebagai penanggung jawab ekonomi keluarga. Pada kenyataannya remaja laki-laki Desa Cileungsi (yang kelak akan menjadi penanggung jawab ekonomi keluarga), sebagian besar mempunyai persepsi negatif tentang kenyamanan kerja di bidang pertanian padi sawah, meskipun mereka cukup sering terlibat dalam kegiatan bertani padi sawah. Hal ini disebabkan anak-anak usia remaja sudah dijadikan pekerja untuk menambah penghasilan orang tuanya, termasuk membantu dengan menjadi tenaga kerja di sektor pertanian, terlepas dari persepsi remaja yang positif atau negatif.

\section{Persepsi Remaja Menurut Faktor Eksternal Remaja}

Penelitian ini menganalisis persepsi remaja terhadap pekerjaan di sektor pertanian padi sawah menurut faktor eksternal remaja, yaitu karakteristik lingkungan remaja. Persepsi remaja (dalam hal pendapatan, peranan, resiko usaha, dan kenyamanan kerja) akan diuji hubungannya dengan 3 karakteristik lingkungan remaja, yaitu status kepemilikan lahan sawah, pengaruh orang tua, dan pengaruh teman sebaya. Pengujian hubungan dilakukan dengan menggunakan Rank Spearman dan Chi Square.

\section{Hubungan antara Persepsi tentang Pendapatan dengan Status Kepemilikan Lahan Sawah}

Hasil pengujian hipotesis antara persepsi tentang pendapatan dengan status kepemilikan lahan sawah ialah tidak terdapat hubungan yang nyata. Dapat dilihat pada Tabel 2, angka yang didapat dengan menggunakan analisis data Chi Square menunjukkan bahwa nilai Asymp. Sig (2 sided) yang diperoleh adalah .441. Nilai ini menunjukkan besaran yang lebih besar dari nilai $p$-value yaitu 0.05. Dapat disimpulkan bahwa baik remaja yang orang tuanya memiliki lahan sawah maupun yang tidak memiliki lahan sawah, tidak terdapat perbedaan persepsi yang signifikan tentang pendapatan dalam bertani. Hal ini tidak sejalan dengan hasil penelitian Herlina (2002) yang dikutip oleh Chandra (2004), yang menyatakan bahwa pemuda yang memiliki lahan akan menilai pekerjaan pertanian secara lebih baik daripada pemuda yang tidak memiliki lahan. Dalam penelitian tersebut, pemuda yang memiliki lahan menganggap usaha pertanian sebagai usaha yang mendatangkan investasi yang menguntungkan, sedangkan yang tidak mempunyai lahan beranggapan bekerja di sektor pertanian berarti bekerja sebagai buruh tani, yang dianggap memiliki tingkat upah yang rendah dan membuat pekerjaan tersebut berstatus sosial ekonomi rendah. Perbedaan hasil penelitian tersebut disebabkan oleh sebagian besar para remaja Desa Cileungsi yang masih percaya bahwa bertani mempunyai nilai ekonomi. Selama masyarakat Indonesia menjadikan beras sebagai bahan pangan utama, maka bertani adalah hal yang cukup menjanjikan untuk membiayai makan sehari-hari dan bersekolah mereka.

\section{Hubungan antara Persepsi tentang Pendapatan dengan Pengaruh Orang tua}

Hasil pengujian hipotesis hubungan antara persepsi tentang pendapatan dengan pengaruh orang tua ialah tidak terdapat hubungan yang nyata. Jika dilihat pada Tabel 2, angka yang didapat dengan menggunakan analisis data Rank 
Spearman yaitu nilai signifikan sebesar .468 dan nilai korelasinya yang diperoleh sebesar .118. Nilai signifikan yang melebihi taraf nyata $(0.05)$ menandakan tidak terdapat hubungan antara persepsi tentang pendapatan di sektor pertanian dengan pengaruh orang tua remaja. Artinya baik remaja yang memiliki pengaruh orang tua yang kuat maupun yang lemah, tidak ada perbedaan persepsi yang signifikan tentang pendapatan dalam bertani. Para orang tua remaja yang mempunyai pengaruh kuat terhadap remaja, meskipun mengenalkan pertanian dari sejak dini, ternyata sebenarnya tidak benar-benar menginginkan anaknya untuk meneruskan jejaknya sebagai petani, melainkan pekerjaan yang pendapatannya lebih tinggi.

\section{Hubungan antara Persepsi tentang Pendapatan dengan Pengaruh Teman Sebaya}

Hasil pengujian hipotesis hubungan antara persepsi tentang pendapatan dengan pengaruh teman sebaya ialah tidak terdapat hubungan yang nyata. Jika dilihat pada Tabel 2, angka yang didapat dengan menggunakan analisis data Rank Spearman yaitu nilai signifikan sebesar .491 dan nilai korelasinya yang diperoleh sebesar .112. Nilai ini menunjukkan besaran yang lebih besar dari nilai $p$-value yaitu 0.05 sehingga dapat dikatakan tidak terdapat hubungan antara persepsi tentang pendapatan dengan pengaruh teman sebaya. Hal ini tidak sejalan dengan hasil penelitian Muksin (2007) yang menyatakan "pemuda memiliki persepsi bahwa mengolah lahan atau sumberdaya lain dinilai belum menjadi kegiatan produktif dan tidak akan banyak menghasilkan uang. Persepsi semacam ini dipengaruhi oleh teman-teman sebaya yang sudah atau sedang bekerja di kota." Sebagian besar teman-teman sebaya dari responden remaja memang memiliki pengaruh yang kuat terhadap responden remaja, namun hal itu tak berlaku dalam hal memilih pekerjaan. Responden remaja memiliki pandangannya tersendiri mengenai pendapatan dalam hal bertani, tanpa terpengaruh oleh teman-temannya.

\section{Hubungan antara Persepsi tentang Peranan dengan Status Kepemilikan Lahan Sawah}

Hasil pengujian hipotesis hubungan antara persepsi tentang peranan dengan status kepemilikan lahan sawah ialah tidak terdapat hubungan yang nyata. Dapat dilihat pada Tabel 2, angka yang didapat dengan menggunakan analisis data Chi Square menunjukkan bahwa nilai Asymp. Sig (2 sided) yang diperoleh adalah .225. Nilai ini menunjukkan besaran yang lebih besar dari nilai $p$-value yaitu 0.05 . Hal tersebut berarti baik remaja yang orang tuanya memiliki lahan sawah maupun yang tidak memiliki lahan sawah, tidak terdapat perbedaan persepsi terhadap peranan dalam bertani. Sebagian besar remaja Desa Cileungsi orang tuanya tidak memiliki lahan sawah, namun hal itu tidak mempengaruhi pandangan remaja terhadap peranan bertani padi sawah dalam hidup mereka.

\section{Hubungan antara Persepsi tentang Peranan dengan Pengaruh Orang tua}

Hasil pengujian hipotesis hubungan antara persepsi tentang peranan dengan pengaruh orang tua ialah tidak terdapat hubungan yang nyata. Jika dilihat pada Tabel 2, angka yang didapat dengan menggunakan analisis data Rank Spearman yaitu nilai signifikan sebesar .737 dan nilai korelasinya yang diperoleh sebesar -.055. Nilai signifikan yang melebihi taraf nyata $(0.05)$ menandakan tidak terdapat hubungan antara persepsi tentang peranan di sektor pertanian dengan pengaruh orang tua remaja. Sebagian besar remaja Desa Cileungsi memiliki pengaruh orang tua yang lemah dalam hal pemotivasian anak untuk bertani, namun hal itu tidak lantas membuat remaja tersebut memiliki persepsi yang negatif terhadap peranan pertanian padi sawah.

\section{Hubungan antara Persepsi tentang Peranan dengan Pengaruh Teman Sebaya}

Hasil pengujian hipotesis hubungan antara persepsi tentang peranan dengan pengaruh teman sebaya ialah tidak terdapat hubungan yang nyata. Jika dilihat pada Tabel 2, angka yang didapat dengan menggunaka dan analisis data Rank Spearman yaitu nilai signifikan sebesar .268 dan nilai korelasinya yang diperoleh sebesar -.179. Nilai ini menunjukkan besaran yang lebih besar dari nilai $p$-value yaitu 0.05 sehingga dapat dikatakan tidak terdapat hubungan antara persepsi tentang peranan dengan pengaruh teman sebaya. Sebagian besar remaja Desa Cileungsi memiliki pengaruh teman sebaya yang kuat. Hal ini sejalan dengan pernyataan Sumarni (2008) yang mengatakan bahwa pada masa remaja lingkungan sosial yang dominan yaitu dengan teman sebayanya. Hubungan persahabatan yang erat ternyata tidak mempengaruhi persepsi remaja 
Desa Cileungsi mengenai pandangan akan suatu pekerjaan.

\section{Hubungan antara Persepsi tentang Resiko Usaha dengan Status Kepemilikan Lahan Sawah}

Hasil pengujian hipotesis hubungan antara persepsi tentang resiko usaha dengan status kepemilikan lahan sawah ialah tidak terdapat hubungan yang nyata. Dapat dilihat pada Tabel 2, angka yang didapat dengan menggunakan analisis data Chi Square menunjukkan bahwa nilai Asymp. Sig (2 sided) yang diperoleh adalah .610. Nilai ini menunjukkan besaran yang lebih besar dari nilai $p$-value yaitu 0.05 . Hal tersebut berarti baik remaja yang orang tuanya memiliki lahan sawah maupun yang tidak memiliki lahan sawah, tidak terdapat perbedaan persepsi terhadap resiko usaha dalam bertani. Berbeda dengan itu, hasil penelitian Herlina (2002) yang dikutip oleh Chandra (2004), mengatakan bahwa pemuda yang memiliki lahan akan menilai pekerjaan pertanian secara lebih baik daripada pemuda yang tidak memiliki lahan. Pada kasus remaja Desa Cileungsi, remaja yang orang tuanya memiliki lahan sawah ataupun tidak, sama-sama memiliki persepsi yang cenderung negatif pada resiko usaha dalam bertani.

\section{Hubungan antara Persepsi tentang Resiko Usaha dengan Pengaruh Orang tua}

Hasil pengujian hipotesis hubungan antara persepsi tentang resiko usaha dengan pengaruh orang tua ialah tidak terdapat hubungan yang nyata. Jika dilihat pada angka yang didapat dengan menggunakan analisis data Rank Spearman yaitu nilai signifikan sebesar .091 dan nilai korelasinya yang diperoleh sebesar .270. Nilai signifikan yang melebihi taraf nyata $(0.05)$ menandakan tidak terdapat hubungan antara persepsi tentang resiko usaha di sektor pertanian dengan pengaruh orang tua remaja. Dorongan dan sosialisasi dari orang tua mengenai bertani padi sawah terhadap remaja, tidak mengubah persepsi mereka akan resiko usaha dalam bertani padi sawah. Meskipun pengaruh orang tuanya kuat untuk mengenalkan dan membiasakan dirinya untuk bertani, para remaja tersebut tidak terpengaruh untuk. Hal ini sejalan dengan hasil penelitian Daulay (2006) yang menyatakan bahwa respon penolakan anak terhadap sosialisasi nilai kerja buruh yang diberikan orang tuanya dikarenakan anak-anak memandang pekerjaan di perkebunan sebagai pekerjaan yang tradisional, kotor, dan tidak menjanjikan. Begitu pun dengan remaja Desa Cileungsi yang sebagian besar memandang bertani padi sawah sebagai pekerjaan yang kotor dan tidak menjanjikan (karena terdapat beberapa resiko seperti gagal panen).

\section{Hubungan antara Persepsi tentang Resiko Usaha dengan Pengaruh Teman Sebaya}

Hasil pengujian hipotesis hubungan antara persepsi tentang resiko usaha dengan pengaruh teman sebaya ialah tidak terdapat hubungan yang nyata. Jika dilihat pada Tabel 2, angka yang didapat dengan menggunakan analisis data Rank Spearman yaitu nilai signifikan sebesar .837 dan nilai korelasinya yang diperoleh sebesar .034. Nilai ini menunjukkan besaran yang lebih besar dari nilai $p$-value yaitu 0.05 sehingga dapat dikatakan tidak terdapat hubungan antara persepsi tentang resiko usaha dengan pengaruh teman sebaya. Lemah atau kuatnya pengaruh teman sebaya terhadap remaja Desa Cileungsi ternyata tidak membuat perbedaan bagi remaja dalam mempersepsikan resiko usaha dalam bertani padi sawah.

\section{Hubungan antara Persepsi tentang Kenyamanan Kerja dengan Status Kepemilikan Lahan Sawah}

Hasil pengujian hipotesis hubungan antara persepsi tentang kenyamanan kerja dengan status kepemilikan lahan sawah ialah tidak terdapat hubungan yang nyata. Dapat dilihat pada Tabel 2, angka yang didapat dengan menggunakan analisis data Chi Square menunjukkan bahwa nilai Asymp. Sig (2 sided) yang diperoleh adalah .331. Nilai ini menunjukkan besaran yang lebih besar dari nilai $p$-value yaitu 0.05 . Hal tersebut berarti baik remaja yang orang tuanya memiliki lahan sawah maupun yang tidak memiliki lahan sawah, tidak terdapat perbedaan persepsi terhadap kenyamanan kerja dalam bertani. Para remaja Desa Cileungsi berpendapat bahwa dengan bertani padi sawah berarti bekerja di tempat yang terbuka dan terkena matahari langsung sehingga para remaja mempunyai persepsi yang cenderung negatif.

\section{Hubungan antara Persepsi tentang Kenyamanan Kerja dengan Pengaruh Orang tua}

Hasil pengujian hipotesis hubungan antara persepsi tentang kenyamanan kerja dengan pengaruh orang tua ialah tidak terdapat hubungan 
yang nyata. Jika dilihat pada Tabel 2 , angka yang didapat dengan menggunakan analisis data Rank Spearman yaitu nilai signifikan sebesar .649 dan nilai korelasinya yang diperoleh sebesar -.074. Nilai signifikan yang melebihi taraf nyata $(0.05)$ menandakan tidak terdapat hubungan antara persepsi tentang kenyamanan kerja di sektor pertanian dengan pengaruh orang tua remaja. Hal ini berarti pengaruh orang tua yang lemah maupun yang kuat terhadap remaja, tidak menunjukkan perbedaan bagi remaja dalam mempersepsikan kenyamanan kerja di bidang pertanian padi sawah. Mereka cenderung mempunyai persepsi negatif mengenai kenyamanan kerja dalam bertani padi sawah, salah satunya yaitu bertani dapat merusak penampilan fisik. Persepsi negatif yang terbentuk merupakan wujud penolakan dari para remaja terhadap sosialisasi nilai kerja yang dilakukan orang tua remaja. Penolakan dari remaja tersebut merupakan hal wajar menurut Daulay (2006) karena kondisi pekerja anak sebagai individu yang masih enerjik, perjalanan hidup yang masih panjang, mobilitas yang masih tinggi, dan kaya dengan harapan-harapan, menciptakan optimisme tertentu yang kontradiktif dengan apa yang dikenalinya sebagai sifat dan kriteria pekerjaan perkebunan. Begitu juga dengan pekerjaan di pertanian padi sawah yang bersentuhan langsung dengan tanah dan lumpur serta pendapatannya yang tidak tetap, dapat membentuk persepsi remaja desa akan pekerjaan pertanian padi sawah yang kotor dan tidak menjanjikan, sementara mereka selaku remaja yang mempunyai perjalanan hidup yang masih panjang dan mobilitas yang masih tinggi, masih mengharapkan pekerjaan yang lebih menjanjikan.

\section{Hubungan antara Persepsi tentang Kenyamanan Kerja dengan Pengaruh Teman Sebaya}

Hasil pengujian hipotesis hubungan antara persepsi tentang kenyamanan kerja dengan pengaruh teman sebaya ialah tidak terdapat hubungan yang nyata. Jika dilihat pada Tabel 2, angka yang didapat dengan menggunakan analisis data Rank Spearman yaitu nilai signifikan sebesar .965 dan nilai korelasinya yang diperoleh sebesar .007. Nilai ini menunjukkan besaran yang lebih besar dari nilai $p$-value yaitu 0.05 sehingga dapat dikatakan tidak terdapat hubungan antara persepsi tentang kenyamanan kerja dengan pengaruh teman sebaya. Lemah atau kuatnya pengaruh teman sebaya terhadap remaja Desa Cileungsi ternyata tidak membuat perbedaan bagi remaja dalam mempersepsikan kenyamanan kerja dalam bertani padi sawah. Para remaja Desa Cileungsi cenderung mempunyai persepsi negatif terhadap kenyamanan kerja dalam bertani padi sawah, salah satunya mengenai jam kerja orang yang bertani dianggap lebih panjang daripada jam kerja orang yang bekerja di luar sektor pertanian. Hal ini sesuai dengan hasil penelitian Faridah (2007) mengenai beberapa alasan petani meninggalkan pekerjaan pertanian, salah satunya yaitu jam kerja di luar pertanian lebih pendek.

\section{SIMPULAN DAN SARAN}

\section{Simpulan}

Remaja Desa Cileungsi memiliki beberapa karaktersitik individu yaitu tingkat pendidikan yang relatif rendah, mayoritas remaja yang memiliki pengalaman pribadi negatif tentang pertanian padi sawah, dan jumlah perbandingan remaja laki-laki dengan perempuan yang sama. Rendahnya tingkat pendidikan remaja disebabkan oleh tingkat pendapatan yang relatif rendah dan masih kurangnya kesadaran akan pentingnya pendidikan sehingga sebagian besar remaja hanya menamatkan pendidikan hingga tingkat SD. Lebih dari separuh jumlah total responden memiliki pengalaman yang negatif terhadap pekerjaan di sektor pertanian padi sawah. Pengalaman yang negatif terbentuk karena beberapa kegiatan bertani seperti pengolahan tanah, pemupukan, penanaman, sampai dengan pemanenan dirasa sangat rumit dan menyusahkan bagi para remaja. Selain itu, remaja juga merasa kegiatan mencangkul tanah tersebut cukup berat sehingga turut membentuk pengalaman yang negatif terhadap pekerjaan di sektor pertanian padi sawah.

Karaktersitik lingkungan yang terdapat pada remaja Desa Cileungsi, yaitu sebagian besar orang tuanya tidak memiliki lahan sawah, pengaruh orang tua yang sebagian besar lemah, dan pengaruh teman sebaya yang sebagian besar kuat. Sebagian besar orang tua remaja bekerja sebagai buruh tani karena banyak diantara mereka yang telah menjual lahan sawahnya. Orang tua para remaja pun memberikan pengaruh yang lemah dalam hal memperkenalkan dan memotivasi remaja akan pertanian karena mereka lebih ingin anak-anaknya bekerja di luar desa yang dianggap lebih menghasilkan. Berbeda 
dengan pengaruh dari orang tua, pengaruh temanteman sebaya justru kuat pada sebagian besar remaja.

Sebagian besar remaja Desa Cileungsi mempunyai persepsi yang positif dalam hal pendapatan dan peranan pada pekerjaan di sektor pertanian padi sawah. Pendapatan dari hasil bertani yang dapat memenuhi kebutuhan hidup sehari-hari (pangan, sandang, dan papan) serta cukup untuk membiayai sekolah, merupakan pengalaman sekaligus keadaan diri remaja yang mendukung terciptanya persepsi yang positif. Peranan sektor pertanian dalam hal menjadi sumber pendapatan penduduk yang hidup di pedesaan, dan dapat menghasilkan produk yang dapat memenuhi kebutuhan pangan sendiri (subsistence) maupun kebutuhan pasar di luar desa, merupakan bahan pertimbangan yang membentuk persepsi yang positif. Dalam hal resiko usaha dan kenyamanan kerja di sektor pertanian, sebagian besar remaja Desa Cileungsi mempunyai persepsi yang negatif. Pengalaman pribadi remaja yang menggambarkan ketergantungan hasil panen pada cuaca dan adanya resiko terserang hama tanaman, membuat sebagian besar remaja mempunyai persepsi yang negatif terhadap resiko usaha pada pekerjaan di sektor pertanian padi sawah. Bekerja di ruang terbuka dan terkena matahari langsung serta melakukan pekerjaan yang kotor, berlumpur dan melelahkan, membuat para remaja Desa Cileungsi mempunyai persepsi yang negatif terhadap kenyamanan kerja pada pekerjaan di sektor pertanian padi sawah.

Terdapat beberapa karakteristik remaja yang berhubungan dengan persepsi remaja terhadap pekerjaan di sektor pertanian padi sawah, yaitu tingkat pendidikan dan jenis kelamin. Variabel tingkat pendidikan berhubungan nyata negatif dengan persepsi remaja terhadap kenyamanan kerja di sektor pertanian padi sawah. Artinya, semakin tinggi pendidikan remaja, maka semakin negatif pula persepsi remaja terhadap kenyamanan kerja di sektor pertanian padi sawah, begitu pun sebaliknya. Hal ini dikarenakan remaja menyadari dengan tingkat pendidikan yang rendah maka peluang untuk bekerja di luar sektor pertanian (yang secara umum dinilai lebih baik dan bergengsi) semakin kecil, sehingga remaja tidak mempermasalahkan kenyamanan kerja di sektor pertanian. Variabel jenis kelamin berhubungan nyata dengan persepsi remaja terhadap peranan pertanian padi sawah. Remaja laki-laki dan perempuan memiliki persepsi yang berbeda dalam hal peranan sektor pertanian. Remaja laki-laki lebih sering turun ke sawah untuk melakukan aktivitas pertanian sehingga lebih banyak remaja laki-laki yang merasakan sendiri peranan bertani dalam hidup mereka, yaitu peranan pertanian sebagai sumber pendapatan penduduk desa dan peranan pertanian dalam memenuhi kebutuhan pangan sendiri maupun pangan pasar di luar desa.

Untuk karakteristik lingkungan remaja, tidak ada satu pun yang berhubungan dengan persepsi remaja terhadap pekerjaan di sektor pertanian padi sawah. Hal ini dikarenakan para orang tua remaja, baik yang memiliki lahan sawah maupun yang tidak, masih meyakini bahwa bertani mempunyai nilai ekonomi sehingga selama masyarakat Indonesia menjadikan beras sebagai bahan pangan utama, maka bertani adalah hal yang cukup menjanjikan. Baik remaja yang memiliki pengaruh orang tua yang kuat maupun yang lemah, tidak ada perbedaan persepsi yang signifikan dalam bertani. Meskipun para orang tua mengenalkan pertanian pada anaknya dari sejak dini, pada kenyataannya mereka tidak benar-benar menginginkan anaknya untuk meneruskan jejaknya sebagai petani, melainkan pekerjaan non pertanian yang penghasilanya lebih tinggi. Begitu juga dengan teman-teman sebaya dari remaja yang berpengaruh kuat maupun lemah pada remaja, tidak memberikan perbedaan bagi remaja untuk mempersepsikan pekerjaan di sektor pertanian padi sawah. Meskipun sebagian besar teman-teman sebaya berpengaruh kuat terhadap responden remaja, namun remaja memiliki pandangan tersendiri dalam hal memilih pekerjaan.

\section{Saran}

Berdasarkan kesimpulan di atas, maka saran yang diberikan adalah:

1. Menurut hasil penelitian ini, para remaja masih memiliki persepsi yang negatif terhadap resiko usaha dalam bertani, salah satunya ialah resiko gagal panen. Untuk itu perlu diterapkan lebih luas lagi kepada masyarakat, khususnya masyarakat desa mengenai asuransi pertanian yang berperan sebagai sistem pengelolaan resiko petani dalam melindungi panennya.

2. Adanya anggapan bahwa bekerja di bidang pertanian merupakan pekerjaan yang rumit, 
sangat berat, dan melelahkan untuk dilakukan, telah membuat persepsi yang negatif pada remaja. Oleh karena itu dibutuhkan penyuluhan pertanian, yang salah satunya membahas mengenai teknik-teknik pengolahan dan penanaman padi kepada petani-petani muda agar mereka tidak mengalami kesulitan lagi saat melakukan kegiatan pertanian tersebut. Selain itu, masyarakat desa juga perlu dibantu dalam hal pengadaan sarana produksi pertanian seperti traktor, agar lebih efisien dalam waktu dan tenaga

\section{DAFTAR PUSTAKA}

[BPS] Badan Pusat Statistik. 2013. Berita Resmi Statistik. Hasil Sensus Pertanian 2013 (Angka Sementara). Jakarta (ID): Badan Pusat Statistik Indonesia.

Calhoun JF, Acocella JR. 1995. Psikologi Tentang Penyesuaian dan Hubungan Kemanusiaan. Semarang (ID): IKIP Semarang Press.

Chandra D. 2004. Persepsi Pemuda Desa Terhadap Pekerjaan Di Sektor Pertanian dan Minat Bekerja Di Kota [skripsi]. Bogor (ID): Institut Pertanian Bogor.

Daulay P. 2006. Sekali Buruh Tetap Buruh: Studi Pembentukan Generasi Buruh di Perkebunan Tembakau Deli, Kabupaten Deli Serdang, Sumatera Utara. [disertasi]. Bogor (ID): Institut Pertanian Bogor.

Faridah K. 2007. Dari Ekonomi Pertanian Ke Ekonomi Industri (Sejarah Kehidupan Sosial Ekonomi Masyarakat Kubangwungu Kecamatan Ketanggungan Kabupaten Brebes Tahun 19692000). [skripsi]. [Internet]. [10:15]. [diunduh 2011 Januari 3]. Tersedia pada: http://digilib.unnes.ac.id/gsdl/collect/skripsi/a rchives/HASHe11f. dir/doc.pdf

Jannah M, Agustiyana E, Astarika AH, Hamdani F, Teresa SM. 2013. Peran Sektor Pertanian dalam Membangun Perekonomian Bangsa dan Peran Sumber Daya dalam Sektor Pertanian [laporan penelitian]. Malang (ID): Universitas Brawijaya

Kaplan HI, Sadock BJ. Grebb JA. 1997. Sinopsis Psikiatri Jilid 1. Ed ke-7. Jakarta (ID): Binarupa Aksara.

Latifah M. 2007. Persepsi dan Ekspektansi Terhadap Profesi Psikologi (Penelitian Deskriptif Pada Mahasiswa Psikologi Universitas Negeri Semarang Tahun 2007). [skripsi]. [Internet]. [12:57]. [diunduh 2011 Januari 9]. Tersedia pada: http://digilib.unnes.ac.id/gsdl/collect/
skripsi/archives/HASH0163/457d3398.dir/ doc.pdf

Liu MNS, Madiono E. 2013. Pengelolaan dan Pengembangan Usaha Hortikultura pada PT. Horti Bima International. [Internet]. [10:00]. [diunduh 2015 Januari 9]. Tersedia pada: http://download.portalgaruda.org/article.php ?article $=194296 \& \mathrm{val}=6509 \&$ title $=$ PENGEL

OLAAN DAN PENGEMBANGAN USAHA HORTIKULTURA PADA PT. HORTI BIMA INTERNATIONAL

Maria U. 2007. Peran Persepsi Keharmonisan Keluarga dan Konsep Diri terhadap Kecenderungan Kenakalan Remaja. [tesis]. [Internet]. [15:10]. [diunduh 2015 Januari 9]. Tersedia pada: http://www.damandiri.or.id/file/Tesis_Ulf ah Maria.pdf

Mastari. 2012. Gambaran Persepsi Masyarakat Kota Medan terhadap Pendidikan Inklusi. [skripsi]. [Internet]. [23:50]. [diunduh 2015 Januari 9]. Tersedia pada: http://repository.usu.ac.id/handle/123456789/ 33613

Martono N. 2010. Statistik Sosial Teori dan aplikasi Program SPSS. Yogyakarta (ID): Gava Media

Muksin. 2007. Kompetensi Pemuda Tani yang Perlu Dikembangkan di Jawa Timur [disertasi]. Bogor (ID): Institut Pertanian Bogor.

Pusat Data dan Informasi Pertanian. 2002. Buletin PDB Sektor Pertanian. 11(44). [Internet]. [12:51]. [diunduh 2010 Desember 29]. Tersedia pada: http://www.deptan.go.id/buletin/ pdb/pdb0 402.pdf

Reza F. 2007. Sikap Petani Terhadap Pengendalian Hama Terpadu (Kasus di Kelurahan Balumbang Jaya, Kecamatan Bogor Barat, Kota Bogor) [skripsi]. Bogor (ID): Institut Pertanian Bogor.

Riswar R. 2013. Hubungan Keaslian Kampung Naga Dengan Pembentukan Identitas Masyarakat Adat [skripsi]. Bogor (ID): Institut Pertanian Bogor.

Robbins SP. 2002. Prinsip-prinsip Perilaku Organisasi. Jakarta (ID): Erlangga.

Rohmad Z. 1998. Peran Pemuda dalam Pembangunan Masyarakat Pedesaan [disertasi]. Bogor (ID): Institut Pertanian Bogor.

Singarimbun M, Effendi S. 2008. Metode Penelitian Survai. Jakarta (ID): Pustaka LP3ES Indonesia.

Siregar H. 1989. Budidaya Tanaman Padi Di Indonesia. Jakarta (ID): PT Sastra Hudaya.

Sumarni DP. 2008. Hubungan antara Ketergantungan terhadap Teman Sebaya dengan Perilaku Antisosial Pada Remaja. [skripsi]. [Internet]. [12:47]. [diunduh 2011 Januari 9]. Tersedia 
pada:

http://etd.eprints.ums.ac.id/2404/1/F1009901 35.pdf

Tampubolon MP. 2008. Perilaku Keorganisasian (Organization Behavior) Perspektif Organisasi Bisnis. Edisi Kedua. Bogor (ID): Ghalia Indonesia.

Tarigan H. 2004. Representasi Pemuda Pedesaan Mengenai Pekerjaan Pertanian: Kasus Pada Komunitas Perkebunan Teh Rakyat di Jawa Barat. ICASERD Working Paper No.29. Pusat Penelitian dan Pengembangan Sosial Ekonomi Pertanian. Departemen Pertanian.

Tarigan K. 2006. Esensi Ekonomi Pertanian. [Internet]. [12:47]. [diunduh 2010 Desember 29]. Tersedia pada: http://ocw.usu.ac.id/course/ download/3160000148-ekonomipertanian/textbook_2.pdf

Walgito B. 2010. Pengantar Psikologi Umum. Edisi Kelima. Yogyakarta (ID): ANDI OFFSET. 